\title{
Moralizing Gods and the Arms-Race Hypothesis of Human Society Growth
}

\author{
Frans L. Roes*
}

Lauriergracht 127-II, 1016 RK Amsterdam, The Netherlands

\begin{abstract}
Following evolutionary ideas, it is argued that human societies grew in size while competing with other societies over preferred habitats. Larger human societies are more successful in competition, but they also experience more pressures to fission. Morality unites a society by limiting infringements upon the rights of other society members. This leads to the prediction that a belief in 'moralizing Gods' is more often found in larger societies. A previous analysis of data from the Standard Cross Cultural Sample and the Ethnographic Atlas support these predictions. However, in this paper the statistics of the tests are largely ignored. The primary aim of this paper is to illustrate that evolutionary logic helps understanding of human social behavior.
\end{abstract}

\section{INTRODUCTION}

Roes and Raymond [1] report empirical support for the following four hypotheses:

1) Conflict and war among human societies is relatively frequent in habitats that are relatively favorable for human living,

2) The frequency of conflict and war is positively correlated with society size,

3) The size of societies is relatively large in preferred habitats, and,

4) Society size is positively correlated with a belief in moralizing gods.

By mentioning the results found, and explaining why they were expected, this article aims to demonstrate the ability of evolutionary theory to generate new hypotheses about human social behavior. As the four hypotheses are without doubt 'sociological', we hope that this article will contribute to a better understanding and fuller acceptance among sociologists of using evolutionary theory to explain human social behavior.

\section{THE EVOLUTIONIST'S VIEW OF LIFE}

Biology is the science of life, and moral behavior is one of the behaviors or characteristics that living organisms may display. As such it is not different from, say, aggression, senescence, the sex-ratio, or clutch size. Each of these phenomena is a candidate for biological explanation, simply by being a characteristic of living organisms.

The most general biological theory is without dispute evolutionary theory, but from that point on differences of opinion surface. So what is the evolutionist's central paradigm?

*Address correspondence to this author at the Lauriergracht 127-II, 1016 RK Amsterdam, The Netherlands; Tel: 020-6259399 / 06-33973734; E-mail: froes@dds.nl; URL:www.froes.dds.nl
Peculiar as it may seem to those unfamiliar with evolution, biologists assume that organisms are designed, by natural selection, solely to reproduce. It is our experience that many readers, not just sociologists, are turned off by a sentence $e^{i}$ like the one preceding, or by similar formulations. The reaction may be ridicule or even hostility. On top of the controversy that the evolutionary paradigm as formulated in this or similar ways may cause, it should also be noted that it differs from a conception of evolutionary theory which is still common today. Many believe, (despite the publication of Dawkins' [2]. The Selfish Gene in 1976 and numerous other publications on that and related subjects), that living organisms behave so as to promote the survival of their own group, or their species, or even the 'balance in nature'. Such conceptions prevent an understanding of evolutionary theory.

Why don't individuals behave so as to promote the survival of their own species, (or their own group, or the balance in nature)? Let us suppose that all individuals of one species indeed do behave so as to preserve their own species. Then one day a mutant emerges which is exactly the same as all other members of the species, except for one thing: It does not attempt to preserve the species. It is completely 'selfish', and devotes all its time and energy to maximally reproducing its own genes. Logic tells us (bearing in mind that all living organisms sooner or later die if only by chance), that it is only a matter of time before everyone is genetically programmed to be 'selfish' as well.

For two reasons: In the first place the mutant has a reproductive advantage over everybody else, because it does not spend time and energy trying to preserve the species. In the second place, it may profit from the attempts of others to help the species (which includes helping the mutant!). Therefore, other things being equal, the mutant will have a greater reproductive success than any other individual. So the frequency of its genes will increase with every generation, until there is not a single individual left who 'selflessly' tries to preserve the species ${ }^{\mathrm{ii}}$. 


\section{WHY DID HUMAN GROUPS OR SOCIETIES HISTORICALLY GREW IN SIZE?}

Why do humans and many other organisms live in groups? In the animal kingdom, living in a group is the exception rather than the rule for sexually reproducing organisms. It occurs frequently in asexual organisms, such as clones, which is easy to understand because each individual is genetically identical, so conflicts of interest are unlikely. But sexually reproducing organisms have different sets of genes, so they are likely to have different and often opposing interests. They compete for mates and resources, especially within the group. Moreover, in close proximity diseases are transmitted more easily. In short, living in groups is costly. Therefore, for groups to persist, definite advantages for those involved have to be identified. Possible advantages fall into five classes:

\section{a) Attraction to a Resource}

Clustering occurs when individuals are attracted to the same resource, like vultures to a carcass. A special case is the individual attracted to the presence of other individuals because the fleeing behaviors or warning calls of those other individuals warn for predators. As mentioned above, many biologists used to believe (and some still do) that living organisms behave so as to preserve the species or the group. An animal emitting a warning call, thereby endangering itself by attracting the attention of the predator but helping other group members, was interpreted as supportive of the idea of "species or group selection". Nowadays, an animal giving warning calls is interpreted as warning close kin (and accidentally helping others) or as signaling to the predator that it is spotted, and it may as well try its luck elsewhere.

\section{b) The Selfish Herd}

As a protection from possible predators, individuals may place other individuals between themselves and the predator. In Hamilton's [3] view, this principle explains the existence of herds, flocks and schools.

\section{c) Kin Selection}

As Hamilton [4] pointed out, individuals can under some circumstances ${ }^{\mathrm{iii}}$ increase their reproductive success by helping closely related individuals, as these closely related individuals carry copies of the genes of the helper. Individuals living in smaller or larger family-units are indeed a common phenomenon. Some of the largest animal societies (ants, termites, wasps, bees, naked mole-rats) actually are nuclear families of enormous size.

\section{d) Common Defense}

In some circumstances (for instance, when it is difficult to flee or to hide), it is advantageous to collectively defend against predators. Individuals collectively defending themselves tend to be kin.

\section{e) Large or Agile Prey}

Sometimes predators cannot bring down large or agile prey animals on their own, and have to work together. And again, cooperating individuals tend to be kin.

\section{HUMAN INTER-GROUP COMPETITION: THE ARMS-RACE HYPOTHESIS}

At first sight, none of the advantages of living in groups mentioned above seems capable of explaining the existence of large human groups or societies. Clustering, hiding behind other members of the group and kin selection obviously fail to explain the historical growth of human societies. And no predator or prey is large enough to force humans to live in very large groups, ranging up to thousands or even millions. Furthermore, "as hunting weapons and skills improved, group sizes should have decreased" [5]. So the existence of large human societies is a mystery, unless other human societies are the predators (and prey) prompting humans to live in large societies. This hypothesis is attractive because it can explain any size of society as parts of balance-of-power races, and it accords with the ecological dominance of humans as a species. As one referee pointed out, this ecological dominance might be the result of humans living in ever larger groups.

In preferred habitats, smaller, weaker groups or societies are overwhelmed by larger societies, or pushed from the habitat to ecological outskirts, like deserts or tundra's. "In effect, organized in competitive groups, humans have become their own principal 'hostile force of nature' " [5].

A sociologist myself, I don't recall ever having read sociological texts where this arms-race hypothesis was discussed, let alone being tested. I used to presume that human societies grew in size because of innovations such as animal husbandry, agricultural techniques, written language, the use of money, etc, and I also presumed that this was common and accepted sociological knowledge. The 'balance or power', or arms-race explanation ${ }^{\text {iv }}$ for the historical growth of human societies seems to be a new interpretation of human history ${ }^{\mathrm{v}}$.

The support we found for the idea of human societies growing in size while competing with other societies will now be briefly discussed. Three testable hypotheses seem to follow from the idea of human intergroup competition. They are:

I. Conflict and war will be relatively frequent in habitats that are relatively favorable for human living.

II. The frequency of conflict and war will be positively correlated with society size.

III. The size of societies will be relatively large in preferred habitats.

(Notice that large society size is not an automatic consequence of rich habitats, because many small societies could instead occupy these habitats).

These hypotheses were tested using the Standard Cross Cultural Sample [6] or SCCS. This is a databank designed for testing hypotheses about human societies and behaviors. With hundreds of variables it describes 186 societies, chosen to represent the known cultural types available. The earliest (as in contrast to later) descriptions of societies were used in an attempt to minimize the influence of western, European culture on the data. This database has become a well established scientific resource for testing hypotheses about human behavior and ecology across different world cultures. 
We found that in the SCCS competition between societies, resource-rich environments, and society size are all positively and significantly associated ${ }^{\mathrm{vi}}$ with one another. We interpret these findings as support for the idea that human societies indeed grew in size while competing with other societies over preferred habitats.

\section{MORALITY, SOCIETY SIZE AND MORALIZING GODS}

Moralizers instruct others about what they should or should not do, and about what is permitted and what is not. Moral rules change, and are certainly not always agreed with. Yet they have a few things in common.

In the first place, moral rules are about helping (or at least not hurting) other people, and they are not about helping self. Immoral behavior typically is helping self at the expense of others. Moral heroes help others often at great costs to themselves ${ }^{\mathrm{vii}}$.

In the second place, help is not given indiscriminately. It is moral to help members of the own group or society, but it is immoral to help enemies of one's own society. With regard to enemies of the own society, moral rules seem reversed: It is usually not considered immoral to help self at the expense of enemies.

Why do moral rules exist? In Alexander's [5] view, "moral systems have been designed to assist group members and explicitly not to assist the members of other competing groups", and morality emerged as a result of intense competition between human societies.

With increasing group or society size, fissioning becomes more likely, but other, large, competing groups could profit from such a split. Conflicts can be quite intense even in small units like families [7], so a large group has to solve the problem of internal conflicts to prevent fission. Alexander suggests that moral rules keep a human group or society together, by proscribing infringements (beyond a certain point) on the rights of other group members. It is these infringements on the rights of others that cause internal conflicts and fissions. Larger societies provide more opportunities for infringements. So if larger societies experience more pressures to split but also pay greater costs for doing so, one may expect them to manifest a greater emphasis on moral rules that prevent in-group infringements.

Apparently, no variables in the SCCS directly measure morality. But the SCCS does contain the variable "High Gods", with the following four values:

(1) Absent or not reported.

(2) Present but not active in human affairs.

(3) Present and active in human affairs but not supportive of human morality.

(4) Present, active, and specifically supportive of human morality.

(5) Missing data

The values 1-3 were recoded into 1 , thus creating a variable which was called Moralizing Gods, with two values: either supportive of human morality, or not.
As a greater emphasis on moral rules that prevent ingroup infringements is expected in larger societies, more often a belief in moralizing gods is also expected in larger societies. Hence the fourth hypothesis.

\section{SOCIETY SIZE IS POSITIVELY CORRELATED WITH BELIEF IN MORALIZING GODS}

Clear support for this hypothesis was found, both in the Standard Cross Cultural Sample and in the Ethnographic Atlas viii. The relation was controlled for by several other variables, such as population density, stratification (class and caste), region (each society is located in one of six different regions), and religion. This last variable codes religions as being either preclassical, classical (Christianity, Islam, Hinduism and Buddhism), or a mix of the two. In each case the relation between society size and belief in moralizing Gods convincingly holds.

Is a belief in a moralizing God or in moralizing Gods a valid indicator of the importance of morality in a society? If morality is important, it probably helps to suggest that a moral rule comes from a source more important than humans. Gods probably help enforce the moral system if they are perceived to be omniscient and omnipotent. Such Gods would detect every transgression and brook no opposition. Also, belief in unlimited rewards and punishment in the afterlife presumably would provide strong incentives to behave morally.

For those in power, several other advantages might be associated with portraying the moral rules as having been imposed by a God or by Gods. In the first place, moral rules imposed by humans invite the suspicion that some members of the society will profit more from these rules than others. Such concerns are alleviated if the rules are convincingly portrayed as having been imposed by impartial Gods without material or reproductive interests. Furthermore, Gods are often considered immortal, so their rules may last for many generations.

If morality is important in a society, one would expect regular checks of people's attitude and opinion about it. This might be one of the functions of public religious rituals where everybody is (perhaps implicitly) supposed to be present. Stated negatively: Those who avoid the rituals, may risk being accused of an unwillingness to accept the moral rules of a society. As one referee remarked: "Social pressure to attend religious ceremonies might be effective in ensuing compliance, in that those present would be implicitly endorsing the moral system".

As to the effect of moralizing Gods on preventing infringements on the rights of other society members: For hundreds of millennia, the major deterrent for wrongdoers was retaliation by the victim. A victim might drum up his kinsmen, so would subsequently the wrongdoer, and the ensuing conflict might eventually split the society. But if the entire population of a society, or at least a large part of it, publicly states belief in a certain moralizing God, that would in certain cases change the situation of the wrongdoer to his or hers disadvantage. Because if a religious moral rule is violated, the wrongdoer not only hurts the victim, also offends the moralizing God and all those who believe in this God. This deters potential wrongdoers, hence less internal 
conflicts within a society. There is a parallel with the treatment of crime in medieval English law, where for instance homicide was a violation of the "king's peace" [8].

Another possible effect of religious moral rules on internal conflicts has to do with education and socialization. Religious moral rules generally need not be explained, (they are literally God-given), which makes them clear and simple guidelines for parents while educating and raising their kids. The result might be a generation less inclined to indulge in activities that may fuel conflicts in a society.

Finally a remark about large societies without a belief in moralizing Gods. Why didn't they succumb to internal conflicts before they grew large? One possibility is that those in power relied heavily on terrorizing and intimidating the population. Another method of preventing internal conflicts would be what Alexander [5] calls 'reproductive opportunity leveling', like socially imposed monogamy and graduatedincome taxes. Yet a third method of preventing internal conflicts, (other than through the influence of belief in moralizing Gods), would be the sharing of some political power with important segments of the population, like in different forms of democracy. So there are many hypotheses left to be tested.

\section{CONCLUDING REMARKS}

Possibly Charles Darwin was wrong, and living organisms, including humans, did not evolve according to the principle of natural selection. That would imply that the reconstruction of human society growth described in this article, including the role of competition between human societies and the influence of morality, was build on a false assumption. Evolutionary theory has been controversial ever since Darwin's days, and it was not the aim of our research to find support for, or refute Darwinian theory. Rather, we used some of the ideas of eminent evolutionists to formulate testable hypotheses about human behavior, and then tested these hypotheses. We believe that it is justified to expect that our understanding of human social behavior will grow, if more sociologists include evolutionary logic in their thinking about human social behavior.

\section{REFERENCES}

[1] Roes FL, Raymond M. Belief in moralizing Gods. Evol Hum Behav 2003; 24(2): 126-35.

[2] Dawkins R. The Selfish Gene. New York: Oxford University Press 1976.

[3] Hamilton WD. Geometry for the selfish herd. J Theor Biol 1971; 31(2): 295- 311

[4] Hamilton WD. The genetical evolution of social behaviour. Theor Biol 1964; 7: 1-52.

[5] Alexander RD. The Biology of Moral Systems. New York: Aldine de Gruyter 1987.

[6] Murdock GP, White DR. Standard Cross-Cultural Sample. Northridge: World Cultures 1985.

[7] Daly M, Wilson M. Evolutionary social psychology and family homicide. Science 1988; 242: 519-24.

[8] Daly M, Wilson M. Homicide. New York: Aldine de Gruyter 1988.

[9] Alexander RD. Natural Selection and Social Exchange. In: Burgess RL, Huston TL, Eds. Social Exchange in Developing Relationships. New York: Academic press 1978.

[10] Trivers RL. Social Evolution. Menlo Park: Benjamin/Cummings Publishers Inc 1985.

[11] Alcock J. Animal Behavior, an Evolutionary Approach. Sunderland, MA: Sinauer Associates, Inc 1993.

[12] Murdock GP, White DR. Ethnographic Atlas. Northridge: World Cultures 1986.

i See Alexander, [9]: 202.

ii It's not just logic which compels modern evolutionists to assume that living organisms behave so as to maximally reproduce their own genes. In several cases, events which previously were in want of an explanation are now neatly explained by modern evolutionists. For instance, reports about males in langur monkeys or lions taking over a pride of females from other males, and subsequently killing the offspring in the pride, were years ago ignored or disputed. Such events apparently did not fit with the idea that creatures act so as for the good of the group, the species, or the balance in nature. Nowadays this kind of infanticide is not only well documented in many species, but its explanation is also widely known (See for instance Trivers, [10], chapter 5: "The Group Selection Fallacy").

iii Hamilton's Rule: Br > C. “... in order for an altruistic act to be adaptive (gene-promoting), its direct fitness cost (C) to the altruist must be less than its indirect fitness benefit (B), which equals the added number of relatives that exist thanks to the altruist's actions multiplied by the coefficient of relatedness (r) between altruist and recipient(s)." [11].

iv The unpredictable nature of hostile human societies increases the need of societies to strengthen themselves. See for instance Variable 896 (Commencement of war) of the Standard Cross Cultural Sample:

By announcement:

By mutual agreement:

By surprise attack

Missing Data

21

104

53

vi Hypother innovations like animal hus

I: Resource base \& External conflict

II External conflict \& Society size

III Resource base \& Society size

See for more statistics: [1].

vii In this context, 'self' can be conceived of in an evolutionary, kin selection manner: Someone who saves an unknown stranger from drowning may receive a medal. But a parent saving its own child will not get such a medal, because the parent is, in a sense, helping self.

viii The Ethnographic Atlas [12] is a data source with fewer variables (little over one hundred) but more (1267) societies.

Received: October 31, 2008

Revised: February 16, 2009

Accepted: March 19, 2009

(C) Frans L. Roes; Licensee Bentham Open.

This is an open access article licensed under the terms of the Creative Commons Attribution Non-Commercial License (http: //creativecommons.org/licenses/by$\mathrm{nc} / 3.0 /$ ), which permits unrestricted, non-commercial use, distribution and reproduction in any medium, provided the work is properly cited. 